Jurnal Ekonomi Modernisasi

http:// ejournal.unikama.ac.id/index.php/JEKO

JEM 13 (2) 2017, 62-77

\title{
Peran Komitmen Organisasi dalam Memediasi Motivasi, Lingkungan Kerja, Kesejahteraan, dan Kepemimpinan Partisipatif terhadap Kinerja
}

\author{
Ilham Arnomo \\ Universitas Hang Tuah
}

\begin{abstract}
The purpose of this research is to analyze the effect of direct and indirect motivation, work environment, well-being and participatory leadership on performance. Research conducted at the Airlangga University Library, data analysis techniques using path analysis. The number of respondents as many as 72 people. The results showed that there were four hypotheses are rejected, namely direct influence of work environment on performance, indirect influence of work environment on performance through direct influence on organizational commitment and leadership participatory on performance and influence indirectly the participatory leadership on performance through organizational commitment The findings in this research suggests that the influence of work environment and participatory leadership still hasn't been able to encourage the staff of the library to committed to the Organization, so that library staff are still not able to contribute optimal performance.
\end{abstract}

Keywords: Motivation; Working Environment; Welfare; Participative Leadership; Organizational Commitment; Performance

\section{Abstrak}

Tujuan penelitian ini adalah untuk menganalisis pengaruh langsung dan tidak langsung motivasi, lingkungan kerja, kesejahteraan dan kepemimpinan partisipatif terhadap kinerja. Penelitian dilakukan di Perpustakaan Universitas Airlangga, teknik analisis data menggunakan analisis jalur. Jumlah responden sebanyak 72 orang. Hasil penelitian menunjukkan bahwa terdapat empat hipotesis yang ditolak yaitu pengaruh langsung lingkungan kerja terhadap kinerja, pengaruh tidak langsung lingkungan kerja terhadap kinerja melalui komitmen organisasi serta pengaruh langsung kepemimpinan partisipatif terhadap kinerja dan pengaruh tidak langsung kepemimpinan partisipatif terhadap kinerja melalui komitmen organisasi. Temuan pada penelitian ini menunjukkan bahwa pengaruh lingkungan kerja dan kepemimpinan partisipatif masih belum dapat mendorong staf perpustakaan untuk berkomitmen terhadap organisasi, sehingga staf perpustakaan masih belum dapat memberikan kontribusi kinerja yang optimal.

Kata kunci: Motivasi; Lingkungan Kerja; Kesejahteraan; Kepemimpinan Partisipatif; Komitmen Organisasi; Kinerja

\footnotetext{
Permalink/DOI : http://dx.doi.org/10.21067/jem.v13i2.1814

Cara mengutip : Arnomo, I. (2017). Peran Komitmen Organisasi dalam Memediasi Motivasi, Lingkungan Kerja, Kesejahteraan, dan Kepemimpinan Partisipatif terhadap Kinerja. Jurnal Ekonomi Modernisasi, 13(2), 62-77. doi:http:/dx.doi.org/10.21067/jem.v13i2.1814
}

Sejarah Artikel : Artikel diterima : April 2016; direvisi : Mei 2017, disetujui : Juni 2017 


\section{Pendahuluan}

Tantangan yang dihadapi oleh perguruan tinggi saat ini cukup besar baik secara internal maupun eksternal. Dalam menghadapi tantangan tersebut, sebuah perguruan tinggi dituntut untuk menjadi "learning organization" yaitu organisasi yang terampil dalam menghasilkan, mendapatkan, dan mentransfer pengetahuan, dan mengubah perilakunya sesuai dengan pengetahuannya yang baru. Perpustakaan perguruan tinggi sesungguhnya telah melakukan sebagian dari istilah "knowledge management" atau pengelolaan pengetahuan terutama pengetahuan yang eksplisit. Dalam konteks "knowledge management", perpustakaan harus melihat kegiatan penggunanya sebagai satu kesatuan yang utuh, yaitu sebagai proses pengetahuan yang meliputi penciptaan, perekaman, penyebaran, pemanfaatan, dan penciptaan kembali pengetahuan (Reda, 2012).

Peran perpustakaan bagi perguruan tinggi sangat penting, ibarat sebuah jantung harus selalu tersebut harus senantiasa memompa ilmu pengetahuan dan teknologi yang segar dan selalu terbarukan kepada para mahasiswa dan pengguna jasa perpustakaan lainnya (Ginting, 2015). Perpustakaan perguruan tinggi juga berkontribusi untuk peningkatan penguasaan teori dan pengembangan penalaran bagi mahasiswa dan dosen yang aktif dalam kegiatan ilmiah. Oleh karena itu, keberadaan perpustakaan sangat menunjang pengembangan kualitas sumber daya manusia guna keberlangsungan pembangunan nasional, sehingga keberadaan perpustakaan selalu diminati banyak kalangan (Larabeng, 2013). Perpustakaan perguruan tinggi perlu mengoptimalkan kinerja organisasi dan kinerja staf karyawan. Hal ini karena kinerja karyawan pada organisasi mempengaruhi kinerja organisasi keseluruhan. Beberapa penelitian terdahulu membuktikan bahwa kinerja karyawan dipengaruhi oleh beberapa faktor antara lain yaitu motivasi (Al Jishi, 2009) yang menyatakan bahwa kinerja seorang karyawan dipegaruhi signifikan oleh motivasi kerja. Selain motivasi karyawan, kinerja karyawan juga ditentukan oleh komitmen karyawan tersebut terhadap organisasi organisasi (Putri, Hakim, \& dan Makmur, 2015). Komitmen karyawan terhadap organisasi tidak hanya meningkatkan kinerja organisasi namun juga memediasi motivasi terhadap kinerja karyawan (Chandraningtyas, Al Musadieq, \& Utami, 2012). Lestariningsih, mengemukakan bahwa kinerja karyawan dapat dipengaruhi lingkungan kerja. Selain itu, lingkungan kerja dapat mempengaruhi komitmen organisasi (Kurniasari dan Halim 2013). Selanjutnya, faktor tingkat kesejahteraan juga mempengaruhi kinerja karyawan (Murtiningsih, 2012). Sedangkan tingkat kesejahteraan karyawan dapat mempengaruhi komitmen organisasi (Chandra, 2013). Pada penelitian lain dijelaskan bahwa kinerja karyawan dipengaruhi oleh kepemimpinan (Rahmat, 2006), dan kepemimpinan berpengaruh terhadap komitmen organisasi (Yuliawan, 2012).

Penelitian tentang faktor-faktor yang mempengaruhi kinerja staf perpustakaan pernah dilakukan oleh Diniaty dan Fairus (2014), hasil penelitian tersebut menunjukkan bahwa terdapat tiga faktor yang mempengaruhi kinerja staf perpustakaan 


\section{Ilham Arnomo / Peran Komitmen Organisasi dalam Memediasi......}

yaitu pendidikan, pengalaman kerja dan pengembangan karyawan berpengaruh secara simultan dan signifikan terhadap kinerja staf perpustakaan Universitas Islam Negeri Sultan Syarif Kasim Riau, pada penelitian ini belum menggunakan variabel lain yang dapat mempengaruhi kinerja karyawan terutama staf perpustakaan. Ose dan Jerome (2011) telah meneliti tentang pengaruh faktor motivasi terhadap kinerja staf perpustakaan di Universitas Benson Idahosa, Nigeria.

Hasil penelitian menunjukkan bahwa faktor-faktor motivasi seperti kepuasan diri dalam bekerja, penempatan kerja yang hatihati, pembayaran tunjangan tepat waktu, promosi staf dan pelatihan kerja untuk staf perpustakaan berpengaruh terhadap kinerja staf perpustakaan. Selanjutnya dijelaskan bahwa penelitian tersebut belum dapat menjawab faktor-faktor lain yang dapat mempengaruhi kinerja staf perpustakaan, seperti menguji pengaruh beberapa variabel antara lain kesejahteraan staf, manajemen yang partisipatif, kompensasi pada staf yang kerja lembur, pelatihan kerja untuk staf, serta motivasi pada staf perpustakaan.

Berdasarkan gap analysis penelitian terdahulu, maka perlu dikembangkan penelitian yang bertujuan untuk mengetahui mencari faktor lain yang mempengaruhi kinerja staf perpustakaan. Sesuai dengan saran penelitian Ose dan Jerome (2011) faktor lain yang perlu dikembangkan dan mempengaruhi kinerja staf perpustakaan adalah pengaruh motivasi, lingkungan kerja, kesejahteraan dan kepemimpinan partisipatif terhadap kinerja staf perpustakaan melalui komitmen organisasi sehingga diharapkan penelitian ini mempu- nyai dampak bagi pengembangan perpustakaan.

\section{Tinjauan Pustaka}

\section{Motivasi}

Menurut Hasibuan, (2008) motivasi merupakan pemberian daya penggerak diri karyawan yang menciptakan semangat kerja supaya karyawan dapat bekerja sama untuk mencapai tujuan organisasi. Artinya, jika seorang karyawan tidak mempunyai motivasi dalam dirinya, maka seorang karyawan itu tidak mempunyai semangat untuk menyelesaikan tugas atau pekerjaannya, sehingga tidak dapat menjalin kerja sama dan kemudian dapat berdampak negatif terhadap tujuan organisasi. Menurut Ponto (2010) tujuan dari pemberian motivasi adalah untuk meningkatkan moral para pekerja agar terbentuk karakter dan sikap sebagai karyawan yang berdedikasi tinggi sehingga akan menciptakan sebuah kepuasan kerja; untuk meningkatkan produktivitas kerja bagi karyawan yang berwujud seperti banyaknya pekerjaan yang dapat diselesaikan sesuai waktu yang ditentukan; untuk mempertahankan kestabilan kerja sehingga rutinitas pekerjaan akan dapat berjalan lancar; untuk meningkatkan disiplin kerja bagi karyawan; untuk menciptakan hubungan kerja yang baik sehingga rutinitas pekerjaan dapat berjalan lancar; untuk meningkatkan loyalitas, kreativitas dan partisipasi, sehingga karyawan berdedikasi dan berkontribusi penuh kepada institusi dengan menunjukkan kreativitas dalam menyelesaikan pekerjaan dengan baik; untuk meningkatkan tingkat kesejahteraan karyawan, artinya karyawan yang termotivasi untuk menunjuk- 
kan kinerja yang terbaik maka akan mempunyai dampak positif kepada institusi untuk memberikan penghargaan yang dapat meningkatkan kesejahteraan karyawan; untuk meningkatkan tanggung jawab terhadap tugasnya; dan untuk meningkatkan efisiensi penggunaan alat bantu menyelesaikan pekerjaan.

Berdasarkan latar belakang teoritis maka hipotesis pada penelitian ini adalah :

$\mathrm{H}_{1}$ : Motivasi berpengaruh langsung dan signifikan terhadap kinerja staf perpustakaan.

\section{Lingkungan Kerja}

Rivai, (2006) mendefinisikan lingkungan kerja sebagai keseluruhan yang ada di sekitar karyawan baik berupa kehidupan sosial, psikologi, fisik dan kondisi sarana prasarana yang dapat menunjang karyawan dalam melaksanakan tugas dan pekerjaannya. Karyawan tidak dapat dipisahkan dari lingkungan kerjanya ketika melakukan pekerjaan karena setiap karyawan akan berinteraksi dengan berbagai kondisi yang terdapat dalam lingkungan kerja. Menurut Sedarmayanti, (2009) bahwa jenis lingkungan kerja dibagi dua yatu lingkungan kerja fisik dan non fisik. Lingkungan kerja fisik merupakan semua keadaan berbentuk fisik yang terdapat disekitar tempat kerja yang dapat mempengaruhi karyawan baik secara langsung maupun tidak langsung (kursi, meja, kondisi suhu dan kelembaban tempat kerja dan sebagainya). Sedangkan lingkungan kerja non fisik merupakan semua keadaan yang terjadi yang berkaitan dengan hubungan kerja, baik hubungan dengan atasan, maupun hubungan dengan sesama rekan kerja. Oleh karena itu, perus- ahaan hendaknya dapat mencerminkan kondisi yang mendukung kerja sama antar tingkat atasan, bawahan maupun yang memiliki status yang sama (Nitisemito, 2000).

Berdasarkan latar belakang teoritis maka hipotesis pada penelitian ini adalah :

$\mathrm{H}_{2}$ : Lingkungan kerja berpengaruh langsung dan signifikan terhadap kinerja staf perpustakaan

\section{Kesejahteraan}

Kesejahteraan didefinisikan terpenuhinya kebutuhan jasmaniah dan rohaniah, baik di dalam maupun diluar hubungan kerja, yang secara langsung atau tidak langsung dapat meningkatkan produktifitas kerja dalam lingkungan kerja yang aman, nyaman dan sehat. Menurut Hasibuan, (2008) bahwa tujuan pemberian kesejahteraan antara lain untuk meningkatkan kesetiaan karyawan kepada perusahaan, sehingga karyawan merasa lebih dihargai dan lebih diperhatikan; untuk pemenuhan kebutuhan karyawan dan keluarganya; untuk memotivasi dan meningkatkan produktifitas kerja, sehingga akan menghasilkan kinerja yang baik; untuk menurunkan tingkat absensi dan turnover karyawan, sehingga karyawan akan memilih berdedikasi dan berkontribusi penuh kepada institusi; untuk menciptakan lingkungan kerja yang nyaman, sehingga dapat mencegah timbulnya ketidakstabilan kinerja karyawan; untuk memperlancar pekerjaan guna mencapai tujuan bersama; untuk memelihara kesehatan dan meningkatkan kualitas karyawan; untuk pengadaan karyawan yang efektif, dalam arti dapat mempertahankan loyalitas dan mengelola dengan baik karya- 
wan yang sudah ada tanpa menambah karyawan baru; untuk mengurangi kecelakaan kerja serta untuk meningkatkan status sosial karyawan.

Adapun jenis kesejahteraan karyawan dikelompokkan sebagai berikut pembayaran atas waktu istirahat, waktu makan siang, cuti sakit, cuti karena alasan pribadi dan lain sebagainya; dan pemberian perlindungan ekonomis terhadap bahaya, misalnya penyakit, cedera dan kematian yang didalamnya termasuk gaji atau upah tahunan, asuransi jiwa, asuransi kesehatan. Selain itu, pemberian pelayanan terhadap karyawan yang berkesinambungan seperti perumahan, makanan, nasehat dan sebagainya juga perlu. Serta pemberian program bantuan kepada karyawan yang diatur undang-undang meliputi: kompensasi purna tugas, asuransi kompensasi pekerja, dan asuransi usia lanjut. (Panggabean S. M., 2004):

Berdasarkan latar belakang teoritis maka hipotesis pada penelitian ini adalah :

$\mathrm{H}_{3}$ : Kesejahteraan berpengaruh langsung dan signifikan terhadap kinerja staf perpustakaan

\section{Kepemimpinan Partisipatif}

Kepemimpinan partisipatif berusaha mensinergikan persamaan kekuatan, persepsi dan berbagi dengan bawahan dalam pemecahan masalah, dengan cara melakukan konsultasi pada bawahan sebelum membuat keputusan (Zhang, Sutting, Fjermestad, \& Tremaine, 2005). Menurut Burhanuddin (1994), bahwa karakteristik gaya kepemimpinan partisipatif antara lain sebagai berikut: kepemimpinan partisipatif dengan cara aktif bekerja sama dengan bawahan; kepemimpinan partisipatif dengan cara mengikutsertakan bawahan secara tepat dalam pengam- bilan keputusan dalam menyelesaikan suatu permasalahan; kepemimpinan partisipatif dengan cara mementingkan tugas guna untuk mempertahankan kepemimpinan dan kekuasaannya guna menjaga kestabilan kinerja institusi keseluruhan; kepemimpinan partisipatif dengan cara menerima setiap saran dan kritik yang membangun dari bawahan demi perkembangan organisasi institusi; dan kepemimpinan partisipatif dengan cara memberikan motivasi secara penuh kepada karyawan sebagai anggota organisasi institusi.

Berdasarkan latar belakang teoritis maka hipotesis pada penelitian ini adalah :

$\mathrm{H}_{4}$ : Kepemimpinan partisipatif berpengaruh langsung dan signifikan terhadap kinerja staf perpustakaan

\section{Kinerja dan Komitmen Organisasi}

Pabundu, (2006) mengemukakan kinerja merupakan hasil kegiatan seseorang atau kelompok dalam suatu organisasi yang dipengaruhi berbagai faktor untuk mencapai tujuan organisasi dalam periode waktu tertentu. Adapun beberapa aspek standar kinerja karyawan meliputi aspek kuantitatif antara lain yaitu proses kerja yang telah dilakukan atau dilalui serta kondisi pekerjaan yang menunjukkan hasil yang baik dan maksimal, waktu yang dipergunakan atau lamanya melaksanakan pekerjaan sesuai dengan ketentuan waktu, jumlah kesalahan yang dilakukan dalam bekerja, serta pemberian pelayanan kepada pimpinan dan rekan kerja dalam menyelesaikan pekerjaan. Adapun yang kedua adalah aspek kualitatif antara lain yaitu: ketepatan menyelesaikan pekerjaan dan kualitas hasil pekerjaan, tingkat kemampuan bekerja; kemampuan menganalisis data dan informasi yang dibu- 
tuhkan dalam menyelesaikan pekerjaan, kemampuan atau kegagalan menggunakan mesin atau peralatan yang digunakan untuk menyelesaikan pekerjaan, serta kemampuan mengevaluasi. (Mangkunegara, 2006): Menurut Maillet (1984) bahwa komitmen organisasi adalah kuatnya pengenalan dan keterlibatan seseorang dalam suatu organisasi tertentu. Hal ini ditandai dengan tiga hal: penerimaan terhadap nilai dan tujuan organisasi; kesedian untuk bekerja sungguh -sungguh untuk kepentingan organisasi; serta keinginan untuk mempertahankan keanggotaan di dalam organisasi.

Komitmen organisasi dapat memediasi motivasi terhadap kinerja karyawan, dengan adanya komitmen yang kuat dalam diri karyawan, maka dapat menimbulkan motivasi bekerja yang baik (Suarjana, Putra, \& Susilawati, 2016). Manggiasih dan Sunardi, (2014) mengemukakan bahwa kinerja karyawan dapat dipengaruhi lingkungan kerja, dan lingkungan kerja dapat mempengaruhi komitmen organisasi (Shalahuddin, 2013), dengan terdukungnya lingkungan kerja yang baik dan kondusif maka dapat menimbulkan komitmen kuat dalam diri karyawan untuk bekerja dengan sungguhsungguh. Faktor tingkat kesejahteraan karyawan juga sangat mempengaruhi kinerjanya (Efendi \& Tamami, 2017), sedangkan tingkat kesejahteraan karyawan juga dapat mempengaruhi komitmen organisasi (Annisa \& Zulkarnain, 2013), sehingga karyawan dapat berkomitmen untuk bekerja dengan baik jika kesejahteraan karyawan dapat dipenuhi oleh perusahaan. Serta kinerja karyawan dapat dipengaruhi oleh gaya kepemimpinan (Warni, 2014) dan gaya kepemimpinan itu sangat berpengaruh terhadap komitmen organisasi Junaedi,
Swasto, \& Utami, 2013), sehingga karyawan berkomitmen bekerja dengan baik jika didukung oleh gaya kepemimpinan yang partisipatif dari pimpinannya.. Berdasarkan latar belakang teoritis hipotesis penelitian ini adalah :

$\mathrm{H}_{5}$ : Motivasi berpengaruh tidak langsung dan signifikan terhadap kinerja staf perpustakaan melalui komitmen organisasi

$\mathrm{H}_{6}$ : Lingkungan kerja berpengaruh tidak langsung dan signifikan terhadap kinerja staf perpustakaan melalui komitmen organisasi

$\mathrm{H}_{7}$ : Kesejahteraan berpengaruh tidak langsung dan signifikan terhadap kinerja staf perpustakaan melalui komitmen organisasi $\mathrm{H}_{8}$ : Kepemimpinan partisipatif berpengaruh tidak langsung dan signifikan terhadap kinerja staf perpustakaan melalui komitmen organisasi.

\section{Metode}

Penelitian ini menggunakan metode survey dengan melakukan penyebaran kuesioner ke seluruh staf perpustakaan Universitas Airlangga Surabaya yang tersebar di 3 kampus terpisah yaitu kampus Unair A, kampus Unair B dan kampus Unair C. Teknik sampling menggunakan sampling jenuh pada seluruh staf perpustakaan Universitas Airlangga Surabaya yang berjumlah 72 orang. Sedangkan teknik analisa data menggunakan path analysis yang bertujuan untuk mengetahui pengaruh langsung variabel-variabel bebas terhadap variabel tergantung dan pengaruh tidak langsung variabel-variabel bebas terhadap variabel tergantung dengan melalui variabel intervening.

Adapun indikator pada penelitian ini dapat dilihat pada Tabel 1. 


\section{Ilham Arnomo / Peran Komitmen Organisasi dalam Memediasi....}

Tabel 1. Variabel dan Indikator Penelitian

\begin{tabular}{|c|c|}
\hline Variabel & Indikator \\
\hline Winardi, & $\begin{array}{l}\text { - Adanya persepsi seseorang mengenai diri sendiri; } \\
\text { - Adanya harga diri; } \\
\text { - Adanya harapan pribadi; } \\
\text { - Adanya kebutuhaan; } \\
\text { - Adanya keinginan; } \\
\text { - Adanya kepuasan kerja; dan } \\
\text { - Adanya prestasi kerja yang dihasilkan. }\end{array}$ \\
\hline $\begin{array}{l}\text { Lingkungan kerja } \\
\text { (Sedarmayanti, 2009) }\end{array}$ & $\begin{array}{l}\text { - Fasilitas kerja sudah memadai dan menggunakan teknologi canggih; } \\
\text { - Ruang kerja dan fasilitas penunjangnya sudah memadai dan sesuai } \\
\text { standar operasional; } \\
\text { - Hubungan dengan pimpinan; dan } \\
\text { - Hubungan kepada rekan kerja. }\end{array}$ \\
\hline $\begin{array}{l}\text { Kesejahteraan } \\
\text { (Panggabean, 2004) }\end{array}$ & $\begin{array}{l}\text { - Adanya pembayaran waktu tidak bekerja atau cuti tahunan; } \\
\text { - Adanya pembayaran gaji; } \\
\text { - Adanya pembayaran tunjangan kinerja; } \\
\text { - Adanya pemberian jaminan pemeliharaan kesehatan; } \\
\text { - Adanya pemberian fasilitas perumahan; } \\
\text { - Adanya program rekreasi rutin bersama rekan kerja tiap tahun; } \\
\text { - Adanya pemberian kesempatan dan beasiswa studi lanjut; dan } \\
\text { - Adanya pembayaran jaminan hari tua atau purna tugas; }\end{array}$ \\
\hline $\begin{array}{l}\text { Kepemimpinan } \\
\text { Partisipatif } \\
\text { (Burhanuddin, 1994) }\end{array}$ & $\begin{array}{l}\text { - Adanya keaktifan pimpinan bekerja sama dengan bawahan; } \\
\text { - Adanya pengikutsertaan bawahan dalam pengambilan keputusan; } \\
\text { - Pimpinan menerima saran dan kritik yang membangun demi perkem- } \\
\text { bangan organisasi; dan } \\
\text { - Adanya pemberian motivasi secara penuh kepada anggota organisasi. }\end{array}$ \\
\hline $\begin{array}{l}\text { Komitmen Organisasi } \\
\text { (Porter et al.(1979) }\end{array}$ & $\begin{array}{l}\text { - Adangan penerimaan kepada nilai dan tujuan organisasi pada masing- } \\
\text { masing anggota organisasi; } \\
\text { - Adanya kesediaan berusaha sungguh-sungguh oleh anggota organisasi } \\
\text { untuk kepentingan organisasi; dan } \\
\text { - Adanya keinginan bertahan menjadi anggota organisasi di dalam organ- } \\
\text { isasi. }\end{array}$ \\
\hline $\begin{array}{l}\text { Kinerja } \\
\text { (Mangkunegara, 2006) }\end{array}$ & $\begin{array}{l}\text { - Adanya waktu yang digunakan pekerja untuk menyelesaikan pekerjaan; } \\
\text { - Adanya kesanggupan untuk bekerja sesuai dengan peraturan yang berla- } \\
\text { ku; } \\
\text { - Adanya aspek jumlah kesalahan yang diperbuat dalam melakukan peker- } \\
\text { jaan; } \\
\text { - Adanya kesanggupan memberikan pelayanan kepada rekan kerja, baik } \\
\text { dalam kondisi sedang ada pekerjaan ataupun tidak dalam melakukan } \\
\text { pekerjaan; } \\
\text { - Adanya kemampuan memanfaatkan fasilitas kerja untuk menyelesaikan } \\
\text { - Aderjaan; dan } \\
\text { diberikan. }\end{array}$ \\
\hline
\end{tabular}




\section{Hasil dan Pembahasan}

\section{Uji Validitas}

Hasil uji validitas dari variabel penelitian motivasi, lingkungan kerja, kesejahteraan, kepemimpinan partisipatif, komitmen organisasi dan kinerja menunjukkan bahwa seluruh nilai koefisien $r_{\text {hitung }}$ pada variabel penelitian tersebut adalah $\geq$ 0,195 , yang berarti seluruh indikator dari keenam variabel penelitian tersebut dinyatakan valid. (Tabel 2).

Tabel 2. Uji Validitas Penelitian

\begin{tabular}{|c|c|c|c|c|}
\hline Variabel & Indikator & $\mathrm{r}_{\text {hirung }}$ & $\mathrm{r}_{\text {tabel }}$ & Keterangan \\
\hline \multirow[t]{7}{*}{ Motivasi } & MO1 & 0,651 & 0,195 & Valid \\
\hline & MO2 & 0,692 & 0,195 & Valid \\
\hline & MO3 & 0,433 & 0,195 & Valid \\
\hline & MO4 & 0,324 & 0,195 & Valid \\
\hline & MO5 & 0,539 & 0,195 & Valid \\
\hline & MO6 & 0,651 & 0,195 & Valid \\
\hline & MO7 & 0,449 & 0,195 & Valid \\
\hline \multirow[t]{4}{*}{ Lingkungan Kerja } & LK1 & 0,742 & 0,195 & Valid \\
\hline & LK2 & 0,643 & 0,195 & Valid \\
\hline & LK3 & 0,688 & 0,195 & Valid \\
\hline & LK4 & 0,650 & 0,195 & Valid \\
\hline \multirow[t]{8}{*}{ Kesejahteraan } & KS1 & 0,719 & 0,195 & Valid \\
\hline & KS2 & 0,701 & 0,195 & Valid \\
\hline & KS3 & 0,628 & 0,195 & Valid \\
\hline & KS4 & 0,658 & 0,195 & Valid \\
\hline & KS5 & 0,599 & 0,195 & Valid \\
\hline & KS6 & 0,587 & 0,195 & Valid \\
\hline & KS7 & 0,620 & 0,195 & Valid \\
\hline & KS8 & 0,743 & 0,195 & Valid \\
\hline \multirow{4}{*}{$\begin{array}{l}\text { Kepemimpinan } \\
\text { partisipatif }\end{array}$} & KP1 & 0,706 & 0,195 & Valid \\
\hline & KP2 & 0,710 & 0,195 & Valid \\
\hline & KP3 & 0,665 & 0,195 & Valid \\
\hline & KP4 & 0,751 & 0,195 & Valid \\
\hline \multirow{3}{*}{$\begin{array}{l}\text { Komitmen organ- } \\
\text { isasi }\end{array}$} & KO1 & 0,539 & 0,195 & Valid \\
\hline & $\mathrm{KO} 2$ & 0,371 & 0,195 & Valid \\
\hline & KO3 & 0,375 & 0,195 & Valid \\
\hline \multirow[t]{6}{*}{ Kinerja } & KIN1 & 0,707 & 0,195 & Valid \\
\hline & KIN2 & 0,633 & 0,195 & Valid \\
\hline & KIN3 & 0,790 & 0,195 & Valid \\
\hline & KIN4 & 0,755 & 0,195 & Valid \\
\hline & KIN5 & 0,816 & 0,195 & Valid \\
\hline & KIN6 & 0,790 & 0,195 & Valid \\
\hline
\end{tabular}

Sumber : Data diolah 2016

\section{Uji Reliabilitas}

Hasil uji reliabilitas dari variabel penelitian motivasi, lingkungan kerja, kesejahteraan, kepemimpinan partisipatif, komitmen organisasi dan kinerja menunjukkan bahwa nilai alpha seluruh variabel penelitian $>0,60$, maka dapat dinyatakan seluruh variabel adalah reliabel. 


\section{Ilham Arnomo / Peran Komitmen Organisasi dalam Memediasi......}

Tabel 3. Hasil Uji Reliabilitas Penelitian

\begin{tabular}{lc}
\hline \multicolumn{1}{c}{ Variabel } & Cronbach alpha \\
\hline Motivasi (MO) & 0,863 \\
\hline Lingkungan Kerja(LK) & 0,885 \\
\hline Kesejahteraan (KS) & 0,919 \\
\hline Kepemimpinan Partisipatif (KP) & 0,891 \\
\hline Komitmen Organisasi (KO) & 0,799 \\
\hline Kinerja (KIN) & 0,943 \\
\hline
\end{tabular}

Sumber : Data diolah 2016

\section{Analisis Pengaruh Langsung Koefisien Jalur}

Pengaruh langsung dari motivasi, lingkungan kerja, kesejahteraan dan kepemimpinan partisipatif terhadap kinerja didapat dengan cara meregresikan motivasi, lingkungan kerja, kesejahteraan, kepemimpinan partisipatif dan komitmen organisasi terhadap kinerja.

Pengaruh langsung motivasi terhadap kinerja ditunjukkan oleh $\beta 1$ yaitu sebesar 0,176 dengan tingkat signifikansi 0,039, maka pengaruh langsung motivasi terhadap kinerja adalah signifikan karena tingkat signifikansi $0,039<0,05$. Pengaruh langsung lingkungan kerja terhadap kinerja ditunjukkan oleh $\beta 2$ yaitu sebesar 0,140 dengan tingkat signifikansi 0,233, maka pengaruh langsung lingkungan kerja terhadap kinerja adalah tidak berpengaruh signifikan karena tingkat signifikansi 0,233 $>0,05$. Pengaruh langsung kesejahteraan terhadap kinerja ditunjukkan oleh $\beta 3$ yaitu sebesar 0,375 dengan tingkat signifikansi 0,001, maka pengaruh langsung kesejahteraan terhadap kinerja adalah signifikan karena tingkat signifikansi 0,001 $<0,05$. Pengaruh langsung kepemimpinan partisipatif terhadap kinerja ditunjukkan oleh $\beta 4$ yaitu sebesar -0,026 dengan tingkat signifikansi 0,843 maka pengaruh langsung kepemimpinan partisipatif terhadap kinerja adalah tidak berpengaruh signifikan karena tingkat signifikansi 0,843>0,05. (Tabel 4).

Tabel 4. Koefisien Jalur Pengaruh Langsung

\begin{tabular}{|c|c|c|c|c|c|}
\hline & \multicolumn{2}{|c|}{$\begin{array}{l}\text { Unstandardized } \\
\text { Coefficients }\end{array}$} & \multirow{2}{*}{$\begin{array}{c}\text { Standardized } \\
\text { Coefficients } \\
\text { Beta }\end{array}$} & \multirow[b]{2}{*}{$\mathrm{t}$} & \multirow[b]{2}{*}{ Sig. } \\
\hline & B & $\begin{array}{l}\text { Std. Er- } \\
\text { ror }\end{array}$ & & & \\
\hline (Constant) & -3.109 & 2.091 & & -1.487 & .142 \\
\hline $\mathrm{MO}$ & .158 & .075 & .176 & 2.107 & .039 \\
\hline LK & .211 & .175 & .140 & 1.203 & .233 \\
\hline KS & .280 & .082 & .375 & 3.405 & .001 \\
\hline KP & -.043 & .214 & -.026 & -.199 & .843 \\
\hline $\mathrm{KO}$ & .994 & .165 & .483 & 6.033 & .000 \\
\hline
\end{tabular}

Sumber: Data diolah 2016 


\section{Analisis Pengaruh Tidak Langsung Koefisien Jalur}

Analisis pengaruh tidak langsung koefisien jalur pada penelitian ini diketahui dari pengaruh tidak langsung motivasi, lingkungan kerja, kesejahteraan, kepemimpinan partisipatif terhadap kinerja melalui komitmen organisasi, (tabel 5)

Tabel 5. Koefisien Jalur Pengaruh Tidak Langsung

\begin{tabular}{|c|c|c|c|c|c|}
\hline & \multicolumn{2}{|c|}{$\begin{array}{l}\text { Unstandardized } \\
\text { Coefficients }\end{array}$} & \multirow{2}{*}{$\begin{array}{c}\text { Standardized } \\
\text { Coefficients } \\
\text { Beta }\end{array}$} & \multirow[b]{2}{*}{$\mathrm{t}$} & \multirow[b]{2}{*}{ Sig. } \\
\hline & B & $\begin{array}{l}\text { Std. Er- } \\
\text { ror }\end{array}$ & & & \\
\hline (Constant) & 5.552 & 1.394 & & 3.983 & .000 \\
\hline $\mathrm{MO}$ & .140 & .053 & .321 & 2.656 & .010 \\
\hline LK & . 135 & .129 & .184 & 1.045 & .300 \\
\hline $\mathrm{KS}$ & -.120 & .059 & -.331 & -2.029 & .046 \\
\hline KP & .192 & .157 & .244 & 1.224 & .225 \\
\hline
\end{tabular}

Sumber : Data diolah 2016

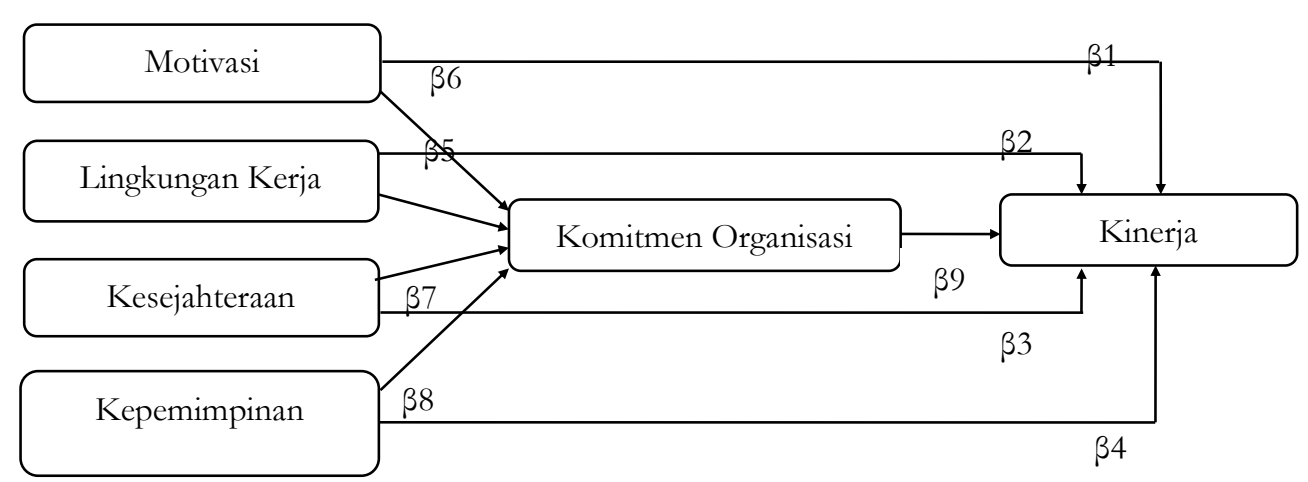

Gambar 1. Parameter Penelitian

Pada gambar 1. diketahui hubungan parameter antar variabel dalam penelitian. Adapun persamaan regresi yang kedua adalah $\beta 5, \beta 6, \beta 7$, dan $\beta 8$ (tabel 5). Nilai parameter $\beta 5$ adalah 0,321 dan signifikan karena tingkat signifikansinya adalah 0,010 $(\alpha<0,05)$. Nilai parameter $\beta 6$ adalah 0,184 dan tidak signifikan karena tingkat signifikansinya adalah $0,300(\alpha>0,05)$. Nilai parameter $\beta 7$ adalah $-0,331$ dan signifikan karena tingkat signifikansinya adalah 0,046 $(\alpha<0,05)$. Nilai parameter $\beta 8$ adalah 0,244 dan tidak signifikan karena tingkat signifikansinya adalah 0,225 ( $\alpha>0,05)$.

Pengaruh tidak langsung motivasi terhadap kinerja melalui komitmen organisasi adalah $\beta 5 * \beta 9$ sebesar $0,321 * 0,483=0,155$ dan signifikan karena kedua parameter pengalinya adalah signifikan. Pengaruh tidak langsung lingkungan kerja terhadap kinerja melalui komitmen organisasi adalah $\beta 6 * \beta 9$ sebesar $0,184 * 0,483=0,088$ dan tidak signifikan karena parameter $\beta 6$ adalah tidak signifikan. Pengaruh tidak langsung kesejahter- 
aan terhadap kinerja melalui komitmen organisasi adalah $\beta 7 * \beta 9$ sebesar $0,331 * 0,483=-0,159$ dan signifikan karena kedua parameter pengalinya adalah signifikan. Pengaruh tidak langsung kepemimpinan partisipatif terhadap kinerja melalui komitmen organisasi adalah $\beta 8^{*} \beta 9$ sebesar $0,244 * 0,483=0,117$ dan tidak signifikan karena parameter $\beta 8$ adalah tidak signifikan.

\section{Pengaruh Langsung Motivasi terhadap Kinerja}

Hasil penelitian menunjukkan motivasi berpengaruh signifikan terhadap kinerja staf perpustakaan Universitas Airlangga Surabaya. Hal ini dapat dijelaskan bahwa motivasi staf perpustakaan Universitas Airlangga Surabaya dalam bekerja cukup tinggi, hal ini karena masing-masing individu mempunyai alasan kuat sebagai motivasi untuk bekerja dengan sebaik-baiknya.

Namun demikian, masih terdapat satu indikator motivasi pada masingmasing individu mempunyai rata-rata rendah, yaitu kurangnya motivasi untuk menunjukkan prestasi kerja, hal ini karena masing-masing individu bekerja bertujuan untuk memenuhi kebutuhan hidup. Hal tersebut sesuai dengan temuan Al Jishi (2009) yang menyatakan bahwa kinerja karyawan dipengaruhi signifikan oleh motivasi.

\section{Pengaruh Langsung Lingkungan Kerja terhadap Kinerja}

Hasil penelitian menunjukkan lingkungan kerja tidak berpengaruh signifikan terhadap kinerja staf perpustakaan Universitas Airlangga Surabaya. Hal ini disebabkan interaksi yang rendah antar rekan kerja dalam menyelesaikan pekerjaan, rendahnya interaksi dalam menyelesaikan pekerjaan disebabkan adanya perangkat kerja berbasis teknologi informasi yang mendukung tugas masing-masing karyawan sehingga masingmasing karyawan terbiasa bekerja secara individu tanpa bantuan rekan kerja. Hal ini bertolak belakang dengan temuan Ningrum et al. (2014) yang menyatakan bahwa kinerja karyawan dipengaruhi signifikan oleh lingkungan kerjanya. Perbedaan ini disebabkan karena kondisi lingkungan kerja penelitian ini berbeda dengan kondisi lingkungan kerja pada penelitian terdahulu.

\section{Pengaruh Langsung Kesejahteraan ter- hadap Kinerja}

Hasil penelitian menunjukkan bahwa kesejahteraan berpengaruh signifikan terhadap kinerja staf perpustakaan Universitas Airlangga Surabaya. Hal ini karena sebagian besar staf perpustakaan bekerja mempunyai tujuan untuk meningkatkan kesejahteraan sehingga sebagian besar staf perpustakaan berusaha menunjukkan kinerja terbaiknya agar kesejahteraannya meningkat. Namun demikian, kesejahteraan staf perpustakaan Universitas Airlangga Surabaya masih belum merata, hal ini ditunjukkan oleh beberapa indikator yaitu belum adanya pemberian fasilitas perumahan dan belum meratanya pemberian beasiswa studi lanjut bagi para staf perpustakaan. Adapun untuk indicator pemberian jaminan hari tua, staf Universitas Airlangga masih belum mempunyai pengalaman karena sampai saat ini masih belum memasuki masa purna tugas. Penelitian ini sesuai dengan Murtiningsih (2012) yang menyatakan bahwa kinerja karyawan dipengaruhi oleh tingkat kesejahteraan. 


\section{Pengaruh Langsung Kepemimpinan Partisipatif terhadap Kinerja}

Hasil penelitian menunjukkan bahwa kepemimpinan partisipatif tidak berpengaruh signifikan terhadap kinerja staf perpustakaan Universitas Airlangga Surabaya. Hal ini karena pendampingan oleh pimpinan dan pemberian kesempatan ikut berpendapat dalam mengambil suatu keputusan hanya sebagai stabilitas kinerja staf perpustakaan Universitas Airlangga Surabaya sehingga kepemimpinan partisipatif masih belum efektif untuk memberikan kontribusi hasil pekerjaan kepada organisasi. Hasil penelitian ini bertolak belakang dengan temuan Arifin dan Dibyo (2016) yang menyatakan bahwa kepemimpinan partisipatif berpengaruh terhadap kinerja karyawan.

\section{Pengaruh Tidak Langsung Motivasi terhadap Kinerja melalui Komitmen Organisasi}

Hasil penelitian menunjukkan bahwa pengaruh tidak langsung motivasi terhadap kinerja staf perpustakaan Universitas Airlangga Surabaya melalui komitmen organisasi adalah signifikan. Terdapat dua koefisien jalur, jalur pertama adalah motivasi pada komitmen organisasi dan jalur kedua adalah komitmen organisasi pada kinerja, hasil kedua koefisien jalur adalah signifikan. Hal ini dapat dijelaskan bahwa masing-masing individu staf perpustakaan Universitas Airlangga Surabaya mempunyai alasan yang kuat sebagai motivasi untuk bekerja dengan sebaik-baiknya. Namun demikian, terdapat satu indikator motivasi pada masing-masing individu yang mempunyai rata-rata rendah, yaitu kurangnya motivasi untuk menunjukkan prestasi kerja karena masing-masing indi- vidu bekerja bertujuan memenuhi kebutuhan hidup. Sehingga motivasi dapat mendorong komitmen organisasi pada staf perpustakaan Universitas Airlangga Surabaya sehingga dapat berkontribusi terhadap kinerja organisasi. Hal tersebut sesuai dengan temuan Al Jishi (2009) yang menyatakan bahwa kinerja karyawan dipengaruhi signifikan oleh motivasi (dan sesuai dengan temuan Putri et al. (2015) yang menyatakan bahwa kinerja karyawan dapat dipengaruhi komitmen organisasi (Putri, Hakim, \& dan Makmur, 2015)

\section{Pengaruh Tidak Langsung Lingkungan Kerja terhadap Kinerja melalui Komit- men Organisasi}

Hasil penelitian menunjukkan pengaruh tidak langsung lingkungan kerja terhadap kinerja staf perpustakaan Universitas Airlangga Surabaya melalui komitmen organisasi adalah tidak berpengaruh signifikan. Terdapat dua koefisien jalur, jalur pertama adalah lingkungan kerja terhadap komitmen organisasi dan jalur kedua adalah komitmen organisasi terhadap kinerja, hasil koefisien jalur kedua adalah tidak signifikan, sehingga pengaruh tidak langsung lingkungan kerja terhadap kinerja melalui komitmen organisasi dapat disimpulkan tidak signifikan. Hal ini karena interaksi antar karyawan secara personal tidak dibutuhkan dalam menyelesaikan pekerjaan operasional sehari-hari karena sudah terdapat fasilitas pernagkat kerja berbasis sistem informasi sehingga masing-masing karyawan dapat menyelesaikan pekerjaan tanpa bantuan rekan kerja. Hasil penelitian ini berbeda dengan hasil penelitian Kurniasari dan Halim (2013) yang menyatakan bahwa lingkungan kerja dapat mempengaruhi komitmen organisasi. 


\section{Ilham Arnomo / Peran Komitmen Organisasi dalam Memediasi......}

\section{Pengaruh Tidak Langsung Kesejahter- aan terhadap Kinerja melalui Komit- men Organisasi}

Hasil penelitian menunjukkan pengaruh tidak langsung kesejahteraan terhadap kinerja staf perpustakaan Universitas Airlangga Surabaya melalui komitmen organisasi adalah signifikan, tterdapat dua koefisien jalur yang dilalui, jalur yang pertama adalah lingkungan kerja terhadap komitmen organisasi dan jalur yang kedua adalah komitmen organisasi terhadap kinerja, adapun hasil dari kedua koefisien jalur tersebut adalah signifikan. Hasil penelitian ini menunjukkan bahwa untuk meningkatkan kinerja karyawan maka upaya yang dapat dilakukan adalah meningkatkan komitmen organisasi, adapun upaya untuk meningkatkan komitmen organisasi maka perlu untuk meningkatkan kesejahteraan karyawan terlebih dahulu. Hal ini sesuai dengan temuan oleh Chandra (2013) yang menyatakan bahwa tingkat kesejahteraan karyawan mempengaruhi komitmen organisasi, dan temuan Putri, et al. (2015) menunjukkan komitmen organisasi berpengaruh signifikan terhadap kinerja karyawan.

\section{Pengaruh Tidak Langsung Kepem- impinan Partisipatif terhadap Kinerja melalui Komitmen Organisasi}

Hasil penelitian menunjukkan pengaruh tidak langsung kepemimpinan partisipatif terhadap kinerja staf perpustakaan Universitas Airlangga Surabaya melalui komitmen organisasi adalah tidak berpengaruh signifikan. Terdapat dua koefisien jalur yang dilalui, jalur yang pertama adalah kepemimpinan partisipatif terhadap komitmen organisasi dan jalur yang kedua adalah komitmen organisasi terhadap kinerja. Hasil dari koefisien jalur yang kedua adalah tidak signifikan, sehingga pengaruh tidak langsung kepemimpinan partisipatif terhadap kinerja melalui komitmen organisasi dapat disimpulkan tidak signifikan. Hal ini dapat dijelaskan bahwa pendampingan oleh pimpinan dan pemberian kesempatan berpendapat dalam mengambil suatu keputusan selama ini masih belum efektif mendorong staf perpustakaan untuk mempunyai komitmen terhadap organisasi, sehingga belum berkontribusi terhadap kinerja staf perpustakaan Universitas Airlangga. Hal tersebut bertolak belakang dengan temuan Yuliawan, et al (2012) yang menyatakan bahwa gaya kepemimpinan berpengaruh terhadap komitmen organisasi.

\section{Simpulan}

Berdasarkan hipotesis dan hasil penelitian, maka simpulan penelitian ini adalah : Motivasi berpengaruh langsung dan signifikan terhadap kinerja staf perpustakaan Universitas Airlangga Surabaya adalah diterima; Lingkungan kerja berpengaruh langsung dan signifikan terhadap kinerja staf perpustakaan Universitas Airlangga Surabaya adalah ditolak; Kesejahteraan berpengaruh langsung dan signifikan terhadap kinerja staf perpustakaan Universitas Airlangga Surabaya adalah diterima; Kepemimpinan partisipatif berpengaruh langsung dan signifikan terhadap kinerja staf perpustakaan Universitas Airlangga adalah ditolak; Motivasi berpengaruh tidak langsung dan signifikan terhadap kinerja staf perpustakaan Universitas Airlangga melalui komitmen organisasi adalah diterima; Lingkungan kerja berpengaruh 
tidak langsung dan signifikan terhadap kinerja staf perpustakaan Universitas Airlangga melalui komitmen organisasi adalah ditolak; Kesejahteraan berpengaruh tidak langsung dan signifikan terhadap kinerja staf perpustakaan Universitas Airlangga melalui komitmen organisasi adalah diterima; Kepemimpinan partisipatif berpengaruh tidak langsung dan signifikan terhadap kinerja staf perpustakaan Universitas Airlangga melalui komitmen organisasi adalah ditolak.

Berdasarkan hasil penelitian, maka akibat langsung yang ditimbulkan dalam organisasi perpustakaan Universitas Airlangga Surabaya dapat dijelaskan bahwa lingkungan kerja perpustakaan Universitas Airlangga Surabaya yang tidak kondusif dapat menimbulkan ketidakharmonisan antar staf perpustakaan, sehingga akan sulit untuk membentuk sebuah tim kerja yang solid dalam sebuah organisasi perpustakaan dan kemudian akan berdampak negatif terhadap kinerja organisasi perpustakaan. Oleh karena itu pihak manajemen perpustakaan harus mengambil kebijakan untuk memfasilitasi staf perpustakaan dengan pelatihan soft skill yang memberkali staf perpustakaan dengan ketrampilan intrapersonal dan interpersonal, sehingga staf perpustakaan dapat mengoptimalkan kemampuan teknis dan akademisnya untuk mencapai kinerja yang baik. Staf perpustakaan juga dapat memiliki ketrampilan sosial dalam menjaga hubungan baik antar sesama rekan kerja dan dengan pimpinan, sehingga staf perpustakaan dapat mencapai kinerja yang optimal.

Kepemimpinan partisipatif yang belum optimal penerapannya akan dapat menimbulkan kesenjangan hubungan antara pimpinan dengan staf perpustakaan, oleh karena itu manajemen perpustakaan Universitas Airlangga Surabaya perlu berperan lebih aktif lagi dalam memberi pendampingan dalam membantu staf perpustakaan untuk menyelesaikan tugas dan pekerjaan. Selain pimpinan harus bisa menerapkan komunikasi dua arah yang transparan dalam hal penyelesaian pekerjaan dan pengambilan suatu keputusan untuk menyelesaikan suatu permasalahan.

Saran untuk pengembangan penelitian kedepan adalah menggunakan objek penelitian yang lebih luas dan lebih dari satu objek penelitian yaitu meneliti faktor-faktor yang dapat mempengaruhi kinerja staf perpustakaan pada beberapa perguruan tinggi swasta dan pada beberapa perguruan tinggi negeri, sehingga akan didapat gambaran yang lengkap faktorfaktor yang dapat mempengaruhi kinerja staf perpustakaan dari kondisi lingkungan kerja, dan penerapan gaya kepemimpinan yang berbeda-beda.

\section{Daftar Pustaka}

Al Jishi, H. A. (2009). Motivation and its Effect on Performance On Nurses in Aramco Health Care. Open University Malaysia.

Annisa, \& Zulkarnain. (2013, April). Komitmen Terhadap Organisasi Ditinjau Dari Kesejahteraan Psikologis Pekerja. Jurnal INSAN, 15(1), 54-62.

Arifin, S. \& Baskoro, D. (2016). Analisis Pengaruh Gaya Kepemimpinan Partisipatif, Motivasi dan Disiplin Kerja Terhadap Kinerja Pegawai Pada PT. Bank Bukopin, TBK Cabang Klaten. Surakarta: Thesis, Universitas Muhammadiyah Surakarta, Surakarta. 


\section{Ilham Arnomo / Peran Komitmen Organisasi dalam Memediasi......}

Burhanuddin. (1994). Analisa Administrasi Manajemen dan Kepemimpinan Pendidikan. Jakarta: Bumi Aksara.

Chandra, Y A. (2013). Pengaruh Kesejahteraan Karyawan Terhadap Komitmen Organisasional Yang Dimoderasi Oleh WLOC (Kontrol Kerja) Pada CV. Kembang Jaya. Kajian Ilmiah Mahasiswa Manajemen. 2(2), 1-7

Chandraningtyas, I., Al Musadieq, M., \& Utami, H. N. (2012). Pengaruh Kepuasan Kerja Dan Motivasi Kerja Terhadap Kinerja Karyawan (Studi pada karyawan PT. Kusuma Karya Persada yang outsourcing di PT. Sasa Inti Probolinggo). Jurnal Profit, 6(2), 32-43.

Diniaty, D. F. (2014). Analisis FaktorFaktor Yang Mempengaruhi Kinerja Pegawai Perpustakaan Universitas Islam Negeri Sultan Syarif Kasim Riau. Jurnal Sains, Teknologi dan Industri, 11(2), 297-304.

Efendi, F., \& Tamami, S. (2017). Pengaruh Tingkat Upah, KEsejahteraan, dan Loyalitas terhadap Kinerja KAryawan pada PT. Angkasa Engineers Indonesia, Jurnal Equilibria, 4(1), 114

Ginting, S. U. (2015). Peran Perpustakaan Perguruan Tinggi Sangat Penting dan Sangat Vital, Sehingga Dapat Juga Disebut Sebagai Organ Jantung Di Dalam Sebuah Perguruan Tinggi. Polteknik Negeri Medan.

Hasibuan, M. S. (2008). Manajemen Sumber Daya Manusia. Jakarta: PT. Bumi Aksara.

Junaedi, D., Swasto, B., \& Utami, H. N. (2013). Pengaruh Gaya Kepemimpinan, Keselamatan dan Kesehatan Kerja, Kepuasan Kerja terhadap Komitmen Organisasional (Studi Pada Karyawan PG. Kebet Baru Malang). Jurnal Profit, 7(1), 127-136.
Kurniasari, D. \& Abdul H. (2013) Pengaruh Lingkungan Kerja Dan Iklim Organisasi Terhadap Komitmen Organisasi Melalui Kepuasan Kerja Karyawan Pada Dinas Pasar Unit Pasar Tanjung Kabupaten Jember. Jurnal Ilmu Ekonomi, 8(2), 273 284.

Larabeng. (2013). Analisis Kinerja Pustakawan Dalam Melayani Pengguna Jasa Perpustakaan Pusat Universitas Tadulako. Jurnal Academica FISIP UNTAD, 5(2), 1093-1100.

Lestariningsih, L, (2012). Pengaruh Kompensasi, Komitmen Karyawan, Lingkungan Dan Iklim Kerja Terhadap Kinerja Karyawan UD Sinar Abadi Di Sidoarjo. Jurnal Akuntansi, Manajemen Bisnis dan Sektor Publik, 8(3), 315-337.

Maillet, Uandre (1984). Mowday, Steers and Porter's (1979) Commitment Questionnaire Compared to Cook and Wall's (1980) Commitment Scale, Psychological Reports. 55(1), 308

Manggiasih \& Sunardi. (2014). Analisis Lingkungan Kerja dan Stres Kerja Dampaknya terhadap Kinerja Karyawan (Studi Kasus di RSUD). Jurnal Ilmiah Manajemen Bisnis, 14 (1), 23-34.

Mangkunegara, A. P. (2006). Evaluasi Kinerja SDM. Jakarta: Eresco.

Murtiningsih, E. (2012). Pengaruh Motivasi, Kesejahteraan dan Fasilitas Kerja terhadap Kinerja Anggota Satuan Polisi Pamong Praja Kabupaten Kediri. Jurnal Ilmu Manajemen, 1(3), 81-93.

Ningrum, N. L., Prasetya, A., \& Riza, M. F. (2014). Pengaruh Lingkungan Kerja Terhadap Kinerja Karyawan (Studi pada Karyawan Auto 2000 Sukun Malang). Jurnal Administrasi Bisnis 11(1), 1-9 
Nitisemito, A. S. (2000). Manajemen Personalia: Manajemen Sumber Daya Manusia. Jakarta: Ghalia Indonesia.

Ose, I. J. (2011). Motivational Factors That Affect Library Staff Performance In Benson Idahosa University, Benin City, Edo State, Nigeria. Journal of Research in Education and Society, 2(3), 14-19.

Pabundu, T. (2006). Budaya Organisasi dan Peningkatan Kinerja Perusahaan. Jakarta: PT. Bumu Aksara.

Panggabean, M. S. (2004). Manajemen Sumber Daya Manusia. Bogor: Ghalia Indonesia.

Ponto, N. N. (2010). Pengaruh Kepemimpinan dan Motivasi Kerja Terhadap Kinerja Karyawan. Jurnal Ilmiah Penelitian Manajemen. 8(1)

Putri, N. E., Hakim, A., \& dan Makmur, M. (2015). Pengaruh Motivasi Kerja Dan Kemampuan Kerja Terhadap Komitmen Organisasional Dan Kinerja Pegawai. Jurnal Ilmu Sosial dan Ilmu Politik. 4(1), 31-42

Rahmat, N. (2006). Analisis Faktor-faktor Yang Mempengaruhi Kinerja Karyawan (Studi Empiris pada PT. Bank Tabungan Negara (Persero) Cabang Bandung). Thesis, Program Pasca Sarjana Universitas Diponegoto, Semarang.

Rivai, V. (2006). Manajemen Sumber Daya Manusia untuk Perusahaan: dari Teori ke Praktik. Jakarta: PT. Raja Grafindo Persada.

Sedarmayanti. (2009). Sumber Daya Manusia dan Produktivitas Kerja. Bandung : CV. Mandar Maju.

Shalahuddin, A. (2013, April). Pengaruh Kepemimpinan dan Lingkungan Kerja terhadap Komitmen Organisasional dan Kinerja Karyawan Pt. Sumber Djantin di Kalimantan Bar- at. Jurnal Manajemen Teori dan Terapan, 6(1), 1-16.

Suarjana, A. A., Putra, I. K., \& Susilawati, N. L. (2016, November). Pengaruh Motivasi Kerja dan Kepuasan Kerja Terhadap Komitmen Organisasi serta Dampaknya terhadap Kinerja Pegawai PLN Rayon Gianyar Di Kabupaten Gianyar. Jurnal Bisnis dan Kewirausahaan, 12(3), 1-11.

Warni, E. D. (2014, Mei). Pengaruh Gaya Kepemimpinan dan Budaya Organisasi terhadap Kinerja Karyawan Pada Sekretariat Daerah Kabupaten Temanggung. Jurnal Riset Manajemen "Provesia", 1(1), 64-77.

Winardi, J. (2007). Motivasi dan Pemotivasian. Jakarta: Raja Grafindo Persada.

Yuliawan, A. K. (2012). Pengaruh Kepemimpinan Terhadap Komitmen Organisasi, Kepuasan Kerja Dan Kinerja (Studi Pada Pegawai Di Lingkungan Sekretariat Daerah Kota Denpasar). E-Jurnal Univeritas Udayana, 1.(2). 107-123

Zhang, Sutting, Fjermestad, J., \& Tremaine, N. (2005). Leadership Style in Virtual Team : Limitations, Solutions and Propositions, Proceedings of the 38th Annual Hawaii International Conference on System Sciences 